LWSA

PAPER - OPEN ACCESS

Pengaruh Pola Asuh Orang Tua Terhadap Perilaku Pengguna Sistem E-Learning Pada Mahasiswa Universitas Sumatera Utara (USU)

\author{
Author $\quad$ : Filia Dina Anggaraeni \\ DOI $\quad: 10.32734 /$ lwsa.v1i1.158 \\ Electronic ISSN : :2654-7058 \\ Print ISSN : 2654-7066
}

Volume 1 Issue 1 - 2018 TALENTA Conference Series: Local Wisdom, Social and Arts

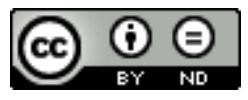

This work is licensed under a Creative Commons Attribution-NoDerivatives 4.0 International License.

Published under licence by TALENTA Publisher, Universitas Sumatera Utara
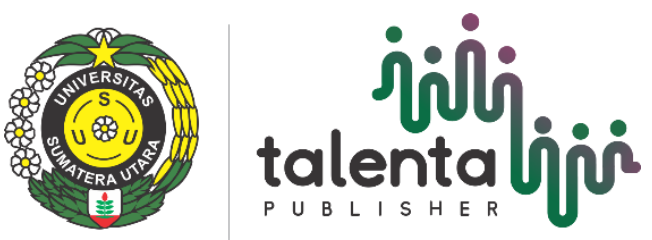


\title{
Pengaruh Pola Asuh Orang Tua Terhadap Perilaku Pengguna Sistem E-Learning Pada Mahasiswa Universitas Sumatera Utara (USU)
}

\author{
Filia Dina Anggaraenia ${ }^{\text {a }}$ dan Ade Rahmawati Siregar ${ }^{\mathrm{a}}$ \\ ${ }^{a}$ Fakultas Psikologi, Universitas Sumatera Utara, Medan, 20155
}

filiadina@yahoo.co.id

\begin{abstract}
Abstrak
Dinamika pembelajaran pada setiap orang dipengaruhi banyak hal. Diantaranya adalah pola asuh orang tua yang diperoleh sejak seseorang dilahirkan di dunia. Pola asuh orang tua yang dimaksud dalam hal ini adalah autoritatif, otoriter, permisif dan pola asuh tidak terlibat (uninvolved). Berbagai pendekatan pola asuh tersebut berpeluang membentuk perilaku seseorang dalam melangsungkan proses pembelajaran hingga jenjang perguruan tinggi yang disebut mahasiswa. Seiring dengan perkembangan teknologi yang berlangsung, mahasiswa melakukan proses pembelajaran diantaranya termasuk bagaimana seseorang memiliki kecenderungan dalam berperilaku dalam menggunakan sistem e-learning. Perilaku pengguna sistem $e$-learning yang dimaksud dalam hal ini adalah individual online (individual self paced-learning online), individual offline (individual self paced-learning offline), grup secara sinkron (group based synchronously)dan grup secara tidak sinkron (group based asynchronously). Penelitian deskriptif ini yang melibatkan 486 responden mahasiswa USU aktif yang diperoleh dengan menggunakan cluster random sampling. Analisis data dilakukan dengan cross tab untuk menjelaskan sejumlah profil individu berdasarkan orientasi pola asuh orang tua serta kecenderungan perilaku pengguna sistem e-learning, suku budaya, dan urutan lahir. Persebaran menunjukkan bahwa kecenderungan pola asuh autoritatif merupakan pengguna sistem e-learning individu online.
\end{abstract}

Kata Kunci: Pola Asuh Orang Tua; E-Learning; Mahasiswa

\section{Pendahuluan}

Dinamika pendidikan di lingkungan perguruan tinggi sudah tidak dapat mengelakan e-learning. Sistem pembelajaran yang lintas batas waktu dan ruang. Sejumlah penelitian telah dilakukan oleh individu-individu untuk mendapatkan gambaran dari dinamika e-learning di lingkungan perguruan tinggi Universitas Sumatera Utara. Sesuatu yang menjadi fenomena dengan latar belakang peran serta latar belakang mahasiswanya. Sebagian penelitian menunjukkan perilaku-perilaku yang berkaitan dengan self regulation learning dan self directed learning.

Fenomena dinamika e-learning dikalangan mahasiswa USU yang dikaitkan dengan regulasi diri dalam belajar, menjadi salah satu kunci penting untuk mencapai prestasi akademik. Sementara penelitian lain banyak menunjukkan bahwa salah satu yang mempengaruhi proses regulasi diri dalam balajar pada mahasiswa adalah pola asuh yang diperoleh dari orang tua. 
Maka menjadi sesuatu yang menarik jika dapat disajikan data empirik berkaitan pola asuh orang tua dengan perilaku pengguna e-learning di kalangan mahasiswa USU.

\subsection{Pola Asuh Orang Tua}

Pola asuh adalah pola interaksi antara anak dengan orang tua meliputi pemenuhan kebutuhan fisik (seperti makan, minum dan lain-lain) dan kebutuhan psikologis (seperti rasa aman, kasih sayang, perlindungan, dan lain-lain), serta sosialisasi norma-norma yang berlaku dimasyarakat agar anak dapat hidup selaras dengan lingkungannya. Dengan kata lain, pola asuh juga meliputi pola interaksi orang tua dengan anak dalam pendidikan karakter anak (Latifah, 2008).

Sementara pola asuh menurut Baumrind (dalam Papalia, dkk., 2008) orang tua tidak boleh menghukum anak, tetapi sebagai gantinya orang tua harus mengembangkan aturan-aturan bagi anak dan mencurahkan kasih sayang kepada anak. Orang tua melakukan penyesuaian perilaku mereka terhadap anak, yang didasarkan atas perkembangan anak karena setiap anak memiliki kebutuhan dan mempunyai kemampuan yang berbeda-beda.

Dari uraian di atas dapat disimpulkan bahwa pola asuh adalah pola interaksi antara orang tua dengan anak meliputi cara orang tua memberikan aturan, hukuman, kasih sayang serta memberikan perhatian kepada anak.

Baumrind (dalam Damon \& Lerner, 2006) mengidentifikasi 3 aspek penting dari orangtua yaitu Warmth,Control dan Communication.Berdasarkan aspek ini, Baumrind (dalam Papalia dkk, 2008) menjelaskan ada tiga gaya pola asuh orang, yaitu: pola asuh autoritatif, otoriter, permisif. Kemudian Aleanor dan Martin (dalam Papalia dkk, 2008) menambahkan satu jenis pola pengasuhan yaitu: tidak terlibat (uninvolved).

\subsection{E-Learning}

Romiszowski (2003) menjelaskan begitu banyak pengertian dari e-learning. Salah satu definisi yang dapat digunakan untuk mengidentifikasikan perilaku pengguna e-learning mengacu pada empat pola pembelajaran $e$ learning. Empat pola tersebut secara umum dibagi menjadi 2 katagori yaitu individu dan kelompok. Kemudian untuk katagori individu dibedakan atas online dan offline. Sedangkan kategori kelompok dibedakan atas synchronously dan asynchronously. Maka keempat pola e-learning tersebut adalah: e-learning individual self paced online, e-learning individual self paced offline, e-learning group based synchronouslye-learning group based asynchronously.

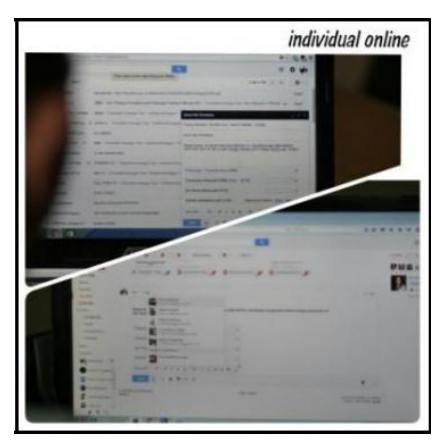

Gambar 1: Ilustrasi individual self-paced online

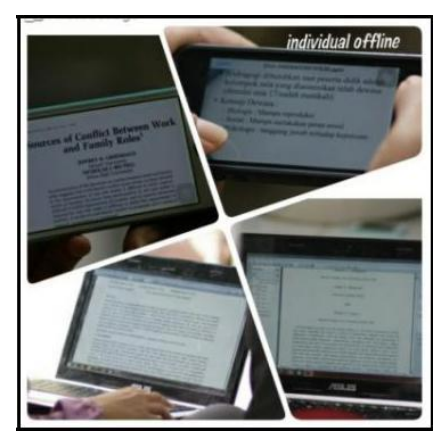

Gambar 2: Ilustrasi individual self-paced offline 


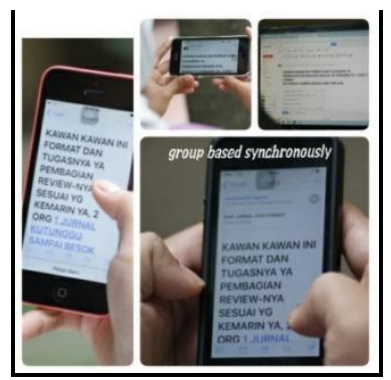

Gambar 3: Ilustrasi Group Based Synchronously

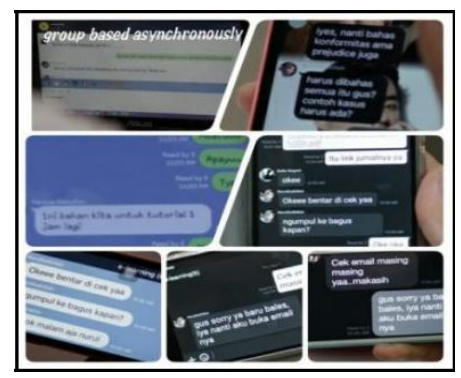

Gambar 4: Ilustrasi Group Based

Synchronously

\section{Metode Penelitian}

Penelitian ini merupakan penelitian yang bersifat deskriptif yang bertujuan untuk melihat pengaruh pola asuh dan perilaku penggunaan sistem e-learning. Menurut Azwar (1999) penelitian deskriptif merupakan metode yang menggambarkan dengan sistematik dan akurat fakta dengan tidak bermaksud menjelaskan, menguji hipotesis, membuat prediksi maupun implikasi. Metode deskriptif bertujuan untuk menggambarkan suatu fenomena yang terjadi, tanpa bermaksud mengambil kesimpulan-kesimpulan yang berlaku secara umum (Hadi, 2000). Responden penelitian ini adalah mahasiswa Universitas Sumatera Utara (USU). Adapun teknik pengambilan sampel adalah dengan menggunakan Cluster Random Sampling.

\section{Hasil dan Diskusi}

\subsection{Hasil}

Berdasarkan hasil pengolahan data dapat dilihat dari total subjek 486 orang, pada Tabel 1 yaitu Crosstabs Pola Asuh Orang Tua dan Perilaku Pengguna Sistem E-learning dapat dilihat pada Tabel 1;

Tabel 1: Crosstabs Pola Asuh Orang Tua dan Perilaku Pengguna Sistem E-learning

\begin{tabular}{|c|c|c|c|c|c|c|c|}
\hline & & & \multicolumn{4}{|c|}{ E-learning } & \multirow[t]{2}{*}{ Total } \\
\hline & & & Online & Offline & Sychronous & Asychronous & \\
\hline \multirow[t]{8}{*}{ Pola Asuh } & Uninvolved & Jumlah & 34 & 20 & 17 & 29 & 100 \\
\hline & & Total \% & $7 \%$ & $4.1 \%$ & $3.5 \%$ & $6 \%$ & $20.6 \%$ \\
\hline & Permisif & Jumlah & 6 & 4 & 4 & 3 & 17 \\
\hline & & Total $\%$ & $1.2 \%$ & $0.8 \%$ & $0.8 \%$ & $0.6 \%$ & $3.5 \%$ \\
\hline & Autoritatif & Jumlah & 109 & 48 & 45 & 71 & 273 \\
\hline & & Total \% & $22.4 \%$ & $9.9 \%$ & $9.3 \%$ & $14.6 \%$ & $56.2 \%$ \\
\hline & Otoriter & Jumlah & 28 & 27 & 19 & 22 & 96 \\
\hline & & Total $\%$ & $5.8 \%$ & $5.6 \%$ & $3.9 \%$ & $4.5 \%$ & $19.8 \%$ \\
\hline \multirow[t]{2}{*}{ Total } & & Jumlah & 117 & 99 & 85 & 125 & 486 \\
\hline & & Total $\%$ & $36.4 \%$ & $20.4 \%$ & $17.5 \%$ & $25.7 \%$ & $100 \%$ \\
\hline
\end{tabular}

Hasil analisis data berdasarkan suku dari responden, baik Batak, Jawa, Mandailing, Karo, Minang, Melayu, Aceh dan lain-lain secara umum lebih banyak dengan pola asuh orang tua autoritatif. Sedangkan untuk masing-masing suku dengan pola autoritatif tersebut persebaran perilaku pengguna sistem e-learning yang terdata adalah seperti yang ditunjukkan Tabel 2. 
Tabel 2: Crosstabs Pola Asuh dan Perilaku Pengguna Sistem E-learning Berdasarkan Suku

\begin{tabular}{|c|c|c|c|c|c|c|c|c|}
\hline \multirow[t]{2}{*}{ Suku } & & & & \multicolumn{4}{|c|}{ Perilaku pengguna sistem E-learning } & \multirow[t]{2}{*}{ Total } \\
\hline & & & & Online & Offline & Sychronous & Asychronous & \\
\hline \multirow[t]{8}{*}{ Batak } & \multirow[t]{8}{*}{ Pola Asuh } & \multirow[t]{2}{*}{ Uninvolved } & Jumlah & 10 & 4 & 5 & 15 & 34 \\
\hline & & & Total \% & $6.7 \%$ & $2.7 \%$ & $3.4 \%$ & $10.1 \%$ & $22.8 \%$ \\
\hline & & \multirow[t]{2}{*}{ Permisif } & Jumlah & 2 & 0 & 2 & 3 & 7 \\
\hline & & & Total $\%$ & $1.3 \%$ & $.0 \%$ & $1.3 \%$ & $2 \%$ & $4.7 \%$ \\
\hline & & \multirow[t]{2}{*}{ Autoritatif } & Jumlah & 29 & 17 & 12 & 20 & 78 \\
\hline & & & Total $\%$ & $19.5 \%$ & $11.4 \%$ & $8.1 \%$ & $13.4 \%$ & $52.3 \%$ \\
\hline & & \multirow[t]{2}{*}{ Otoriter } & Jumlah & 3 & 11 & 6 & 10 & 30 \\
\hline & & & Total \% & $2 \%$ & $7.4 \%$ & $4.0 \%$ & $6.7 \%$ & $20.1 \%$ \\
\hline \multirow[t]{2}{*}{ Total } & & & Jumlah & 44 & 32 & 25 & 48 & 149 \\
\hline & & & Total $\%$ & $29.5 \%$ & $21.5 \%$ & $16.8 \%$ & $32.2 \%$ & $100 \%$ \\
\hline \multirow[t]{8}{*}{ Jawa } & \multirow{8}{*}{ Pola Asuh } & \multirow[t]{2}{*}{ Uninvolved } & Jumlah & 5 & 5 & 1 & 6 & 17 \\
\hline & & & Total \% & $4.7 \%$ & $4.7 \%$ & $.9 \%$ & $5.6 \%$ & $15.9 \%$ \\
\hline & & \multirow[t]{2}{*}{ Permisif } & Jumlah & 2 & 2 & 2 & 0 & 6 \\
\hline & & & Total \% & $1.9 \%$ & $1.9 \%$ & $1.9 \%$ & $.0 \%$ & $5.6 \%$ \\
\hline & & \multirow{2}{*}{ Autoritatif } & Jumlah & 28 & 12 & 14 & 14 & 68 \\
\hline & & & Total \% & $26.2 \%$ & $11.2 \%$ & $13.1 \%$ & $13.1 \%$ & $63.6 \%$ \\
\hline & & \multirow{2}{*}{ Otoriter } & Jumlah & 10 & 3 & 2 & 1 & 16 \\
\hline & & & Total $\%$ & $9.3 \%$ & $2.8 \%$ & $1.9 \%$ & $.9 \%$ & $15.0 \%$ \\
\hline \multirow[t]{2}{*}{ Total } & & & Jumlah & 45 & 22 & 19 & 21 & 107 \\
\hline & & & Total \% & $42.1 \%$ & $20.6 \%$ & $17.8 \%$ & $19.6 \%$ & $100 \%$ \\
\hline \multirow[t]{6}{*}{ Mandailing } & Pola Asuh & Uninvolved & Jumlah & 5 & 3 & 2 & 0 & 10 \\
\hline & & & Total \% & $10.2 \%$ & $6.1 \%$ & $4.1 \%$ & $.0 \%$ & $20.4 \%$ \\
\hline & & Autoritatif & Jumlah & 6 & 5 & 6 & 8 & 25 \\
\hline & & & Total $\%$ & $12.2 \%$ & $10.2 \%$ & $12.2 \%$ & $16.3 \%$ & $51.0 \%$ \\
\hline & & Otoriter & Jumlah & 2 & 3 & 5 & 4 & 14 \\
\hline & & & Total $\%$ & $4.1 \%$ & $6.1 \%$ & $10.2 \%$ & $8.2 \%$ & $28.6 \%$ \\
\hline Total & & & Jumlah & 13 & 11 & 13 & 12 & 49 \\
\hline & & & Total \% & $26.5 \%$ & $22.4 \%$ & $26.5 \%$ & $24.5 \%$ & $100 \%$ \\
\hline Karo & Pola Asuh & Uninvolved & Jumlah & 4 & 2 & 3 & 1 & 10 \\
\hline & & & Total $\%$ & $14.8 \%$ & $7.4 \%$ & $11.1 \%$ & $3.7 \%$ & $37.0 \%$ \\
\hline & & Permisif & Jumlah & 0 & 1 & 0 & 0 & 1 \\
\hline & & & Total $\%$ & $.0 \%$ & $3.7 \%$ & $.0 \%$ & $.0 \%$ & $3.7 \%$ \\
\hline & & Autoritatif & Jumlah & 5 & 2 & 3 & 2 & 12 \\
\hline & & & Total \% & $18.5 \%$ & $7.4 \%$ & $11.1 \%$ & $7.4 \%$ & $44.4 \%$ \\
\hline & & Otoriter & Jumlah & 1 & 2 & 1 & 0 & 4 \\
\hline & & & Total $\%$ & $3.7 \%$ & $7.4 \%$ & $3.7 \%$ & $0 \%$ & $14.8 \%$ \\
\hline Total & & & Jumlah & 10 & 7 & 7 & 3 & 27 \\
\hline & & & Total $\%$ & $37.0 \%$ & $25.9 \%$ & $25.9 \%$ & $11.1 \%$ & $100 \%$ \\
\hline Melayu & Pola Asuh & Uninvolved & Jumlah & 3 & 1 & 2 & 2 & 8 \\
\hline & & & Total $\%$ & $8.8 \%$ & $2.9 \%$ & $5.9 \%$ & $5.9 \%$ & $23.5 \%$ \\
\hline & & Permisif & Jumlah & 1 & 0 & 0 & 0 & 1 \\
\hline & & & Total $\%$ & $2.9 \%$ & $.0 \%$ & $.0 \%$ & $0 \%$ & $2.9 \%$ \\
\hline & & Autoritatif & Jumlah & 8 & 2 & 3 & 5 & 18 \\
\hline & & & Total \% & $23.5 \%$ & $5.9 \%$ & $8.8 \%$ & $14.7 \%$ & $52.9 \%$ \\
\hline & & Otoriter & Jumlah & 4 & 1 & 1 & 1 & 7 \\
\hline & & & Total \% & $11.8 \%$ & $2.9 \%$ & $2.9 \%$ & $2.9 \%$ & $20.6 \%$ \\
\hline Total & & & Jumlah & 16 & 4 & 6 & 8 & 34 \\
\hline & & & Total \% & $47.1 \%$ & $11.8 \%$ & $17.6 \%$ & $23.5 \%$ & $100 \%$ \\
\hline Minang & Pola Asuh & Uninvolved & Jumlah & 1 & 0 & 1 & 0 & 2 \\
\hline & & & Total $\%$ & $2.6 \%$ & $0 \%$ & $2.6 \%$ & $0 \%$ & $5.1 \%$ \\
\hline & & Permisif & Jumlah & 1 & 1 & 0 & 0 & 2 \\
\hline
\end{tabular}




\begin{tabular}{|c|c|c|c|c|c|c|c|c|}
\hline & & \multirow{3}{*}{ Autoritatif } & Total \% & $2.6 \%$ & $2.6 \%$ & $0 \%$ & $0 \%$ & $5.1 \%$ \\
\hline & & & Jumlah & 12 & 3 & 3 & 7 & 25 \\
\hline & & & Total \% & $30.8 \%$ & $7.7 \%$ & $7.7 \%$ & $17.9 \%$ & $64.1 \%$ \\
\hline & & \multirow[t]{2}{*}{ Otoriter } & Jumlah & 3 & 4 & 2 & 1 & 10 \\
\hline & & & Total \% & $7.7 \%$ & $10.3 \%$ & $5.1 \%$ & $2.6 \%$ & $25.6 \%$ \\
\hline \multirow{2}{*}{\multicolumn{2}{|c|}{ Total }} & & Jumlah & 17 & 8 & 6 & 8 & 39 \\
\hline & & & Total \% & $43.6 \%$ & $20.5 \%$ & $15.4 \%$ & $20.5 \%$ & $100 \%$ \\
\hline \multirow[t]{6}{*}{ Aceh } & \multirow[t]{6}{*}{ Pola Asuh } & \multirow[t]{2}{*}{ Uninvolved } & Jumlah & 2 & 1 & 2 & 2 & 7 \\
\hline & & & Total \% & $8.3 \%$ & $4.2 \%$ & $8.3 \%$ & $8.3 \%$ & $29.2 \%$ \\
\hline & & \multirow[t]{2}{*}{ Autoritatif } & Jumlah & 7 & 2 & 2 & 3 & 14 \\
\hline & & & Total \% & $29.2 \%$ & $8.3 \%$ & $8.3 \%$ & $12.5 \%$ & $58.3 \%$ \\
\hline & & \multirow[t]{2}{*}{ Otoriter } & Jumlah & 1 & 0 & 2 & 0 & 3 \\
\hline & & & Total \% & $4.2 \%$ & $.0 \%$ & $8.3 \%$ & $0 \%$ & $12.5 \%$ \\
\hline \multirow{2}{*}{\multicolumn{2}{|c|}{ Total }} & & Jumlah & 10 & 3 & 6 & 5 & 24 \\
\hline & & & Total \% & $41.7 \%$ & $12.5 \%$ & $25.0 \%$ & $20.8 \%$ & $100 \%$ \\
\hline \multirow[t]{6}{*}{ Lain- Lain } & \multirow[t]{6}{*}{ Pola Asuh } & \multirow[t]{2}{*}{ Uninvolved } & Jumlah & 4 & 4 & 1 & 3 & 12 \\
\hline & & & Total \% & $7.0 \%$ & $7.0 \%$ & $1.8 \%$ & $5.3 \%$ & $21.1 \%$ \\
\hline & & \multirow[t]{2}{*}{ Autoritatif } & Jumlah & 14 & 5 & 2 & 12 & 33 \\
\hline & & & Total \% & $24.6 \%$ & $8.8 \%$ & $3.5 \%$ & $21.1 \%$ & $57.9 \%$ \\
\hline & & \multirow[t]{2}{*}{ Otoriter } & Jumlah & 4 & 3 & 0 & 5 & 12 \\
\hline & & & Total \% & $7.0 \%$ & $5.3 \%$ & $0 \%$ & $8.8 \%$ & $21.1 \%$ \\
\hline \multirow{2}{*}{\multicolumn{2}{|c|}{ Total }} & & Jumlah & 22 & 12 & 3 & 20 & 57 \\
\hline & & & Total \% & $38.6 \%$ & $21.1 \%$ & $5.3 \%$ & $35.1 \%$ & $100 \%$ \\
\hline
\end{tabular}

Data penelitian ini juga mengungkap bahwa urutan kelahiran dengan jumlah responden 10 ke atas adalah sampai pada urutan lahir keenam. Secara umum dari urutan lahir pertama hingga enam responden juga mendapatkan pola asuh orang tua autoritatif. Sedangkan perilaku pengguna sistem e-learning masing-masing adalah seperti terlihat pada tabel 3:

Tabel 3: Crosstabs Pola Asuh dan Perilaku Pengguna Sistem e-learning Berdasarkan Urutan Kelahiran

\begin{tabular}{|c|c|c|c|c|c|c|c|c|}
\hline \multirow{2}{*}{$\begin{array}{l}\text { Urutan } \\
\text { Kelahiran }\end{array}$} & & & & \multirow[b]{2}{*}{ Online } & \multicolumn{3}{|c|}{ Perilaku E-learning } & \multirow[t]{2}{*}{ Total } \\
\hline & & & & & Offline & Sychronous & Asychronous & \\
\hline \multirow[t]{8}{*}{ Pertama } & Pola Asuh & Uninvolved & Jumlah & 14 & 7 & 7 & 13 & 41 \\
\hline & & & Total \% & $7.3 \%$ & $3.6 \%$ & $3.6 \%$ & $6.7 \%$ & $21.2 \%$ \\
\hline & & Permisif & Jumlah & 1 & 1 & 1 & 0 & 3 \\
\hline & & & Total $\%$ & $.5 \%$ & $.5 \%$ & $.5 \%$ & $.0 \%$ & $1.6 \%$ \\
\hline & & Autoritatif & Jumlah & 44 & 24 & 19 & 27 & 114 \\
\hline & & & Total $\%$ & $22.8 \%$ & $12.4 \%$ & $9.8 \%$ & $14.0 \%$ & $59.1 \%$ \\
\hline & & Otoriter & Jumlah & 13 & 10 & 6 & 6 & 35 \\
\hline & & & Total $\%$ & $6.7 \%$ & $5.2 \%$ & $3.1 \%$ & $3.1 \%$ & $18.1 \%$ \\
\hline \multirow[t]{2}{*}{ Total } & & & Jumlah & 72 & 42 & 33 & 46 & 193 \\
\hline & & & Total $\%$ & $7.2 \%$ & $3.2 \%$ & $1.6 \%$ & $7.2 \%$ & $19.2 \%$ \\
\hline \multirow[t]{8}{*}{ Kedua } & Pola Asuh & Uninvolved & Jumlah & 9 & 4 & 2 & 9 & 24 \\
\hline & & & Total $\%$ & $7.2 \%$ & $3.2 \%$ & $1.6 \%$ & $7.2 \%$ & $19.2 \%$ \\
\hline & & Permisif & Jumlah & 3 & 2 & 1 & 1 & 7 \\
\hline & & & Total $\%$ & $2.4 \%$ & $1.6 \%$ & $.8 \%$ & $.8 \%$ & $5.6 \%$ \\
\hline & & Autoritatif & Jumlah & 29 & 6 & 7 & 26 & 68 \\
\hline & & & Total \% & $23.2 \%$ & $4.8 \%$ & $5.6 \%$ & $20.8 \%$ & $54.4 \%$ \\
\hline & & Otoriter & Jumlah & 7 & 8 & 5 & 6 & 26 \\
\hline & & & Total $\%$ & $5.6 \%$ & $6.4 \%$ & $4.0 \%$ & $4.8 \%$ & $20.8 \%$ \\
\hline \multirow[t]{2}{*}{ Total } & & & Jumlah & 48 & 20 & 15 & 42 & 125 \\
\hline & & & Total $\%$ & $38.4 \%$ & $16.0 \%$ & $12 \%$ & $33.6 \%$ & $100 \%$ \\
\hline \multirow[t]{2}{*}{ Ketiga } & Pola Asuh & Uninvolved & Jumlah & 5 & 5 & 6 & 5 & 21 \\
\hline & & & Total $\%$ & $5.5 \%$ & $5.5 \%$ & $6.6 \%$ & $5.5 \%$ & $23.1 \%$ \\
\hline
\end{tabular}




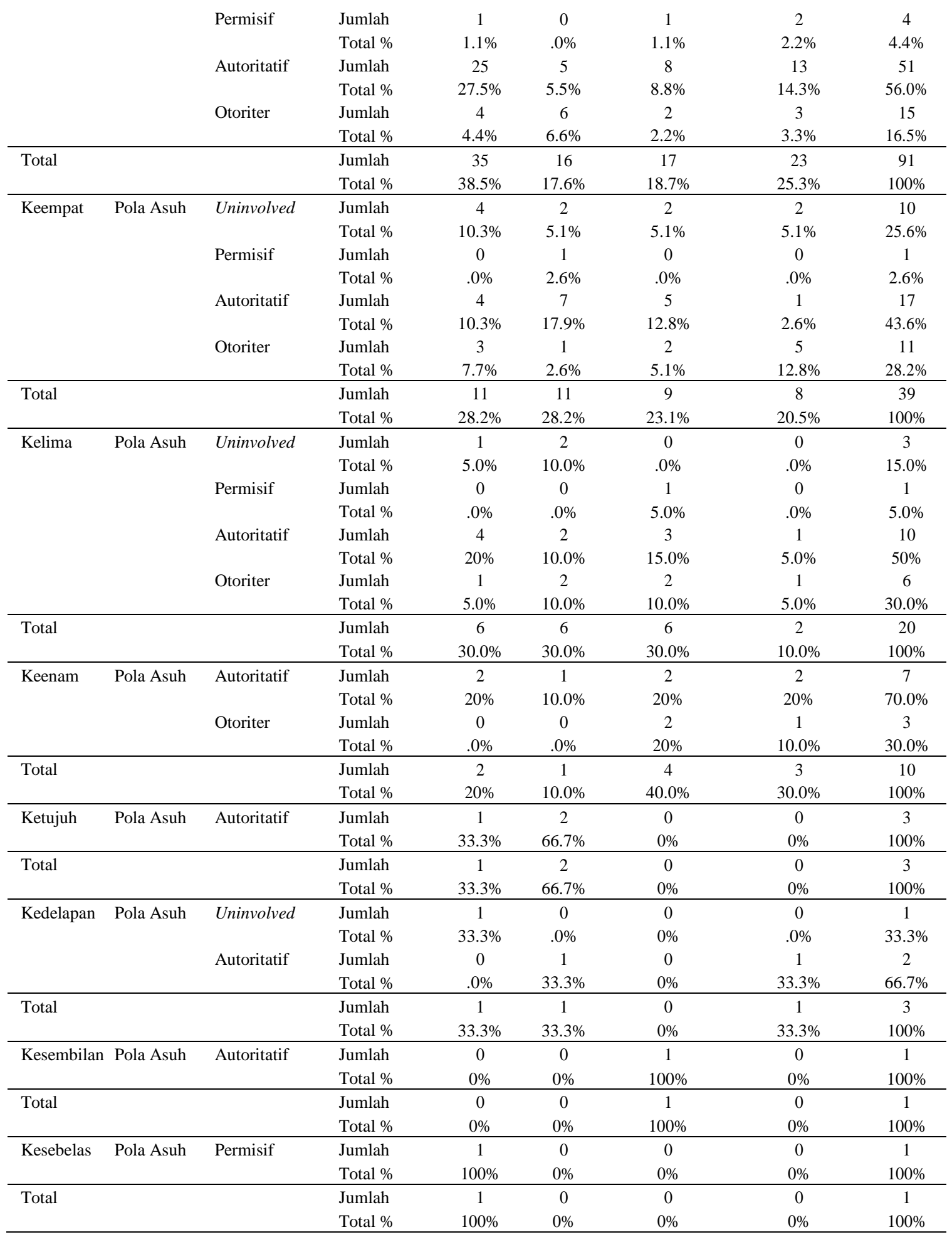




\subsection{E-Learning}

Secara umum hasil analisis data penelitian ini menunjukkan bahwa pola asuh orang responden adalah autoritatif. Baumrind (dalam Damon dan Lerner, 2006) menjelaskan bahwa gaya pola asuh autoritatif menetapkan aturan dan pedoman bahwa anak-anak mereka diharapkan untuk mengikuti arahan orang tua namun gaya pengasuhan ini jauh lebih demokratis. Mereka tegas, tapi tidak mengganggu dan membatasi. Metode disiplin mereka yang mendukung, bukan hukuman. Mereka ingin anak-anak mereka untuk bersikap tegas serta tanggung jawab sosial, dan mandiri serta koperatif. Hal ini juga ditunjukkan dalam penelitianSiregar (2006) tentang Motivasi Mahasiswa Berprestasi ditinjau dari Pola Asuh bahwa pola asuh autoritatif berkontribusi lebih tinggi menumbuhkan motivasi mahasiswa berprestasi.

Tentunya banyak hal yang mempengaruhi motivasi mahasiswa berprestasi, diantaranya sistem pembelajaran $e$ learning. Mahasiswa dengan pola asuh yang yang sudah dibawa sejak lahir dan tumbuh di tengah keluarga secara tidak langsung membentuk perilaku-perilaku yang kemudian dapat menjadi pola dalam belajar dan beradaptasi di lingkungan pendidikannya. Sejumlah penelitian tentang e-learning pada mahasiswa USU dilakukan oleh, Duma \& Anggaraeni, (2009) tentang Sikap Mahasiswa USU Terhadap Pola-Pola E-learning; menunjukkan bahwa secara sikap mahasiswa USU bergerak dari negatif, netral dan positf. Hal ini menunjukkan bahwa mereka telah mengetahui serta berpeluang telah berperilaku sebagai pengguna e-learning tersebut sehingga sikap mereka dapat diukur.

Dari hasil analisis data pada penelitian ini, belum dapat ditunjukkan atau pun dibuktikan nilai kontribusi pengaruh dari pola asuh dengan gaya mana pun pada perilaku pengguna sistem e-learning pada mahasiswa USU ini. Namun beberapa penelitian yang pernah dilakukan oleh Marpaung \& Anggaraeni, (2012) tentang Hubungan Antara Motivasi Belajar dengan Self-Regulated Learning Pada Mahasiswa USU yang Mengalami Proses Pembelajaran E-learning, kemudian penelitian Maulidini \& Anggaraeni, (2012) tentang Perbedaan Self Directed Learning Ditinjau Dari Pola Pembelajaran E-learning Pada Mahasiswa Universitas Sumatera Utara, menunjukkan hasil motivasi belajar mahasiswa berkaitan dengan proses e-learning sudah terbangun. Bahkan beberapa penelitian lebih spesifik yang dilakukan pada mahasiswa Fakultas Psikologi USU tentang Gambaran Persepsi Mahasiswa tentang Kualitas Elearning (Andra \& Anggaraeni, 2012) serta Hubungan antara Persepsi terhadap E-learning dengan Motivasi Belajar (Sitanggang, \& Anggaraeni, 2012) menjadi benang merah yang menguatkan peluang perilaku pengguna sistem $e$ learning ini dapat dikaji keterkaitannya dengan pola asuh.

Pada penelitian ini dilakukan crosstabs berdasarkan suku bangsa dengan variabel pola asuh orang tua serta perilaku pengguna sistem e-learning sebab telah dilakukan penelitian bahwa diyakini Prestasi Akademik dapat ditinjau dari Pola Asuh Etnis (Putri \& Siregar, 2013).

\section{Penutup}

Sebagaimana dijelaskan pada bagian awal penelitian ini bukan untuk menarik kesimpulan.

1. Secara umum pola asuh orang tua dari responden yang terjaring mayoritas adalah autoritatif.

2. Kecenderungan perilaku pengguna sistem e-learning tersebar baik secara individu mau pun grup, serta masing-masing pola dari online, offline, synchronous mau pun asynchronous

\section{References}

[1] Andra, Marisa \& Anggaraeni, Filia Dina. 2012. Gambaran Persepsi Mahasiswa tentang Kualitas E- learning di Fakultas Psikologi Universitas Sumatera Utara. Skripsi. http://repository.usu.ac.id/handle/123456789/33750. Diakses tanggal 20 Mei 2014.

[2] Bouchard, Paul. 2009. Some Factor to Consider When Designing Semi-Autonomous Learning Environments. Electronic Journal ofe-learning Volume 7 Issue 2 2009, (93 - 100). www.ejel.org. Diakses tanggal 18 Mei 2014.

[3] Cherry, Kendra. 2014. http://psychology.about.com/od/developmentalpsychology/a/parenting-style.htm. Diakses tanggal 20 Mei 2014.

[4] Damon, D., \& Learner, R.M. (2006). Handbook of child psychology. Sixth edition. Canada : John Wliley \& Son.

[5] Duma, Stevie \& Anggaraeni, Filia Dina. 2009. Sikap Mahasiswa USU Terhadap Pola-Pola E-learning. Skripsi. http://repository.usu.ac.id/handle/123456789/14535. Diakses tanggal 20 Mei 2014.

[6] Handayani,W. (2006). Psikologi keluarga. Jakarta : Pustaka Utama.

[7] Hijazi, Samer., 2003. Interactive Technology Impact on Quality Distance Education. Electronic Journal ofe-learning, Volume 1 Issue 1 (2003) 35-44. www.ejel.org. Diakses tanggal 18Mei 2014.

[8] Irmawati., 2004. Motivasi Berprestasi Dan Pola Pengasuhan Pada Suku Bangsa Batak Toba Di Desa Parparean II. Tesis. http://repository.usu.ac.id/handle/123456789/6472 . Diakses tanggal 18 Mei 2014. 
[9] Latifah, M. (2008). Peranan keluarga dalam pendidikan karakter anak. [terhubung berkala] http://www.tumbuh-kembanganak.blogspot.com.html. [21 Januari 2012].

[10] Marini, Liza dan Andriani, Elvi. 2009. Perbedaan Asertivitas Remaja ditinjau dari Pola Asuh Orang tua. Skripsi. http://repository.usu.ac.id/handle/123456789/15714 . Diakses tanggal 18 Mei 2014.

[11] Marpaung, Rina Melati \& Anggaraeni, Filia Dina. 2012. Hubungan Antara Motivasi Belajar dengan Self-Regulated Learning Pada Mahasiswa USU yang Mengalami Proses Pembelajaran E-learning Skripsi. http://repository.usu.ac.id/handle/123456789/34214. Diakses tanggal 20 Mei 2014.

[12] Maulidini, Nazlely \& Anggaraeni, Filia Dina. 2012. Perbedaan Self Directed Learning Ditinjau Dari Pola Pembelajaran E-learning Pada Mahasiswa Universitas Sumatera Utara. Skripsi. http://www.publicpriorart.org/xml/20/1/1/2524/46585/20.1.1.2524.46585.xml. Diakses tanggal 20 Mei 2014.

[13] Nasution, Rida Masniari. 2012. Gambaran Kemandirian Remaja dengan Pola Asuh Permisif. Skripsi. http://repository.usu.ac.id/handle/123456789/34205. Diakses tanggal 18 Mei 2014.

[14] Nurani, A. T. (2004). Pengaruh kualitas perkawinan, pengasuhan anak dan kecerdasan emosonal terhadap prestasi belajar anak [Tesis]. Bogor: Fakultas Pertanian, Institut Pertanian Bogor.

[15] Putri, Henny Rahmayani \& Siregar, Ade Rahmawati. 2013. Prestasi Akademik ditinjau dari Pola Asuh Etnis. Skripsi. http://repository.usu.ac.id/handle/123456789/37558 . Diakses tanggal 20 Mei 2014.

[16] Romiszowski, Alexander., 2003. The future of E-learning as an educational innovation: Factors_influencing project success and failure. Revista Brasileira de Aprendizagem Aberta e a Distância , São Paulo, Setembro. 2003. http://www.abed.org.br/revistacientifica/Revista_PDF_Doc/2003_Future_E_Learning_Educational_Innovation_Alexander_Romiszowski.pd f. Diakses tanggal 20 Mei 2014.

[17] Santrock, J.W. (2003). Life Span Development. Jilid 1: Edisi Kelima. Penerbit Erlangga.

[18] Siregar, Ade Rahmawati. 2006. Motivasi Mahasiswa Berprestasi ditinjau dari Pola Asuh. Skripsi. http://repository.usu.ac.id/handle/123456789/7334. Diakses tanggal 18 Mei 2014.

[19] Papalia, D. E., Wendkos, S., \& Feldman, R. D. (2008)..Human Development. Edisi 10 Buku 1. Penerbit Salemba Humanika.

[20] Sitanggang, Martua \& Anggaraeni, Filia Dina. 2012. Hubungan antara Persepsi terhadap E-learning dengan Motivasi Belajar pada Mahasiswa Fakultas Psikologi USU. Skripsi. http://repository.usu.ac.id/handle/123456789/34508 Diakses tanggal 20 Mei 2014. 